УДК 130.121:159.9.019.2

ТЕТЯНА КОЛИЧЕВА кандидат філософських наук, дочент кафедри філософії та соиіології, Український державний університет залізничного транспорту (м.Харків, Україна) e-mail: kolychevatatjana@ukr.net, ORCID 0000-0001-7710-5319

ВАДИМ ЛЕБЕДСВ кандидат філософських наук, дочент кафедри філософії та соиіологї, Український державний університет залізничного транспорту (м.Харків, Україна) e-mail: wz551a@gmail.com ORCID 0000-0002-8673-7075

\title{
СУЧАСНА ТРАКТОВКА ГЕШТАЛЬТУ: АНТРОПОЛОГІЧНІ АСПЕКТИ
}

Важливу роль у сучасному трактуванні гештальту $\epsilon$ його розгляд не тільки 3 епістемологічних позицій, але й з точки зору саморефлексії людини. Таким чином, сучасний антропологічний вимір гештальту полягає в тому, що пізнання особистості потрібно здійснювати, виходячи 3 процесу іiі індивідуалізації. Тобто, важливий сам процес процесс формоутворення. Розглянемо способи досягнення цього. Ідеї сучасного гештальту перегукуються з думками екзистенційно-аналітичної території особистості. Процес надбання будь-яким об'єктом або явищем своєї форми, особливо коли мова йде про людську особистість і границі її проявів, починається зі створення дистанції між об'єктом та тим, що його оточує. Саме дистанція дозволяє індивіду з'ясувати свої імпліцитні почуття. Тобто, картина світу особистості будується на тому резонансі, який людина отримує як відповідь на свої почуття та емоції, але при цьому резонанс може відбуватися або у формі конструкції, або у формі реконструкції. Великого значення надається естетичний аспект створення гештальту. В рамках створеного гештальту людина пристосовується до реальності і одночасно пристосовує до себе реальності тим, що вона шукає способи не тільки зрозуміти для себе реальність, але й зробити іiі естетично сприятливою. Таким чином, в рамках сучасної гештальт-теорії естетичний фактор створення форми полягає у поєднанні досяжного на пізнавальному та емоційному рівнях без посилання на певні цінності. Іншими словами, коли порушується структура гештальту, будь-то структура особистості, або структура ситуації, що відбувається за рахунок усунення певних частин форми, автоматично створюється нова структура гештальту, але зі збереженням частини попереднього гештальту. Антропологічний прояв сучасної гештальт-теорії передбачає - аутентичність. Внутрішня реальність 3 iї ірраціональним компонентом, та включає до себе певні перетворення реальності, але ці перетворення повинні носити імпульс для подальшого іiі розвитку. Сучасна гештальт-теорія підкреслює, що доступ до своїх правильних почуттів та думок виникає, коли $\epsilon$ відповідальність між змістом отриманого досвіду та сутністю людини. Низка сучасних авторів розкриває поняття «реляційний гештальт» тобто, динамічний гештальт», на який впливає відносність обставин. Діалог є ще одним антропологічним аспектом сучасного гештальту. Відомо, що одним з головних принципів діалогу є включеність. Включеність передбачає не тільки поглинання до внутрішніх аспектів життя або ситуації іншого, а ще й визнання іншого особою включеності. Тобто, діалог формується завдяки включеності обох сторін з участю емоцій, а конструктивний висновок діалогу формується завдяки створенню загального континууму усвідомлення реальності сторін, що створює гештальт як нову форму спілкування. Сучасна гештальт-теорія ставить нові стратегічні завдання в галузі міжособистісних відносин соціальних аспектів розвитку особистості та суспільства, а також пропонує варіанти їх рішення. 
Ключові слова: гештальт; антропологія; реляційний гештальт; аутентичність; естетичний аспект; діалог; континуум усвідомлення

Актуальність статті пов'язана 3 необхідністю розширення інструментаріїв пізнання та самопізнання людини для іiі самовизначення у різних антропологічних аспектах. Особливо важливими такі можливості людини є у світі сучасного інформаційного простору. Навіть у творах сучасної масової культури ми можемо бачити відлуння гештальту (наприклад, досить популярним $\epsilon$ мотив, коли герої твору повинні зібрати докупи частини стародавнього магічного артефакту, щоб врятувати всесвіт).

Метою статті $€$ вивчення концепту «гештальт» у філософськоантропологічному аспекті для структурування, узагальнення та функціонування культурного досвіду.

Об’єктом дослідження $є$ концепт «гештальт», який означає структуру, образ форму, конфігурацію, яка існує за притаманними їй законами i впорядковує розмаїття окремих явищ антропологічного змісту.

Ступінь розробленості проблеми. До виникнення терміну «гештальт» у філософії використовувалось поняття «форма». Класичною філософією досліджувались особливості перцепції, як процеси виникнення стійких образів, зокрема, цим займались такі філософи, як Арістотель, Д.Локк, І.Кант та представники Вюрцбургської школи Гештальт-напрямок зародився, як теорія цілісного перцептивного образу і розвивався представниками Х.Еренфельсом. Головним методологічним принципом теорії гештальту $\epsilon$ Е.Гуссерлем, М.Мерло-Понті, М.Анрі, Ж.Л. Маріон. Феноменологічні підходи є плідними там, де аналізується людська об'єктивність, і тому стає актуальним питання про використання ідеї феноменології в гештальті в ракурсі антропологічного аспекту-соціокультурного конструювання.

Особливе значення у формуванні гештальт-теорії та виділенні концепту «гештальт» має психоаналіз, який репрезентує ідеї розвитку людини, виходячи з особистих можливостей та потреб, самопізнання, самоїнтерпретації. Зокрема, психоаналіз Лакана надає можливість через функціонування гештальту дослідити механізми утворення символічного.

Сучасні постмодерністські теорії суб'єктивності мають значення для дослідження гештальту в антропологічному аспекті. Наприклад, концепція гештальту як «насиченого феномену» Ж.Л.Маріона, феноменологічна концепція М.Анрі самоафіціювання життя, що демонструє себе у гештальті як маніфестація цілісності особистості.

До цих ідей соціокультурного конструювання себе цілісною особливістю, враховуючи механізми символічного, має значення дія гештальт-теорії на загально філософському рівні дослідження унікальності життя людини. Це передбачає розкриття механізмів розширення індивідуального досвіду людини, що гештальт є філософсько - антропологічним поняттям.

Виклад матеріалу. Важливу роль у сучасному трактуванні гештальту $є$ його розгляд не тільки 3 епістемологічних позицій, але й 3 точки зору саморефлексії людини. Таким чином, сучасний антропологічний вимір 
гештальту полягає в тому, що пізнання особистості потрібно здійснювати, виходячи $з$ процесу іiі індивідуалізації. Тобто, важливий сам процес процесс формоутворення. Розглянемо способи досягнення цього.По-перше, центрування на ситуації дозволяє взаємодіяти 3 усім спектром людської діяльності - думати, діяти, говорити, досліджувати. Ідеї сучасного гештальту перегукуються 3 думками екзистенційно-аналітичної території особистості. Процес надбання будь-яким об’єктом або явищем своєї форми, особливо коли мова йде про людську особистість і границі їі проявів, починається зі створення дистанції між об’єктом та тим, що його оточує. Саме дистанція дозволяє індивіду з'ясувати свої імпліцитні почуття.

Як стверджує Ж-М. Робін, сучасний досліджувач гештальту, «саме почуття є основою будь-якого досвіду» (Робін, 2016, с. 184). Говорячи, про почуття слід висловити думку, що до недавнього часу трактування почуттів людини викривлювало іiі соціальне життя. Навіть Н. Гудмен казав про те, що якщо психотерапія полягає в тому, щоб адаптувати людей під хворе суспільство, що значить займатися терапією?» (Робін, 2016, с. 186). Тобто, картина світу особистості будується на тому резонансі, який людина отримує як відповідь на свої почуття та емоції, але при цьому резонанс може відбуватися або у формі конструкції, або у формі реконструкції. Ж-М. Робін ставить цьому зв’язку коло питань: «Конструювати - що? Деконструювати-що? Чи можна реконструювати для іншого, або ми деконструюємо іншого» (Горлач, Заветный, Кострикин, 2010, с. 181). Іншими словами, почуття викликаються, певними системами значень, які в якості модальностей вже закладені у свідомість людини у формі установок, або спогадів. За допомогою таких модальностей ми оцінюємо іншу людину, яка підпадає під вплив створених нами форм. (Гингер, 2010, с. 76).

Якщо говорити про конструкцію, як процес, протилежний реконструкції, слід пам'ятати, що наш досвід ніколи не буде досвідом іншої людини, і тому слід прагнути того, щоб «людина в результаті отримувала не низку фіксованих смислів, а щоб саме досвід міг слугувати фоном, 3 якого ми можемо брати інформацію для конструювання та реконструювання, щоб будувати різні значення» (Робін, 2016, с.189). В такому разі почуття не будуть обмежені певними модальностями, і зможуть створювати співвідношення фігури та фону у гештальтах.

Продовжуючи обговорювати аспекти процесу надбання явищем форми i роблячи акценти на саме антропологічних аспектах, слід розглянути естетичні фактори створення форми. У повсякденному сприйнятті, як стверджує Ж.-М. Робін «чуттєвість у відчутті може відтворити смисл і буття конкретної людини тут та тепер викликати до життя нові форми суб' єктивації» (Робін, 2016, с 149). Тобто, антропологічне значення гештальту, який прагне досягти своєї прегнантної форми, полягає у тому, щоб нові ракурси дослідження, нові кути зору брали участь у створенні гештальту, незважаючи на їх ірраціональні моменти. Класична гештальт-теорія більшою частиною орієнтувалась на принципи доцільності, який перегукується з естетичними аспектами. 
Таким чином, в рамках сучасної гештальт-теорії естетичний фактор створення форми полягає у поєднанні досяжного на пізнавальному та емоційному рівнях без посилання на певні цінності. Ця думка слідує зі специфічних властивостей гештальту як утворення, що несе у собі глибину та реальність досвіду. Д.Блум підкреслює, що «досвід скоріше оцінюється через притаманну йому внутрішню форму, ніж у порівнянні з будь-якою зовнішньою формою, яка базується на змісті цього досвіду» (Робін, 2016, с.156).

Якщо розглядати питання естетичних факторів, слід відмітити, що кожна особистість користується своїми власними, індивідуально створеними художніми засобами, тобто виробляє моделі дії та способи існування всередині тієї реальності, що існує. В рамках створеного гештальту людина пристосовується до реальності і одночасно пристосовує до себе реальності тим, що вона шукає способи не тільки зрозуміти для себе реальність, але й зробити іiі естетично сприятливою.

Тут слід зазначити думку, що в сучасному трактуванні гештальту форми у гештальті вже $\epsilon$ не встановленими формами, «а формами у русі, знов жеефемерними» (Робін, 2016, с. 154). Доказом тому може слугувати той факт, що у XXI столітті мистецтво стає недовговічним, нетривалим і створює нові специфічні формати, наприклад, інсталяції або перформанси.

Естетично сприятлива реальність завжди динамічна. Арнхейм відмічає, що «будь-яке сприйняття є цілісним візуальним поняттям» (Шестаков, 2015, с. 42). I, продовжуючи його думку, можна сказати, що динамічна цілісність починається саме з викривлень. Ми, можемо це бачити на прикладах мистецтва. Арнхейм розповідає: «Чому викривлені фігури Жоана Міро здаються комічними, чого ніколи не відбувається зі скульптурами Джакометті і рідко відбувається 3 малюнками Пікассо? I Джакометті вся фігура викривлюється рівномірно, і тому вона являє світ у іншому вимірі. Фігури Міро нерівномірні в своїх розмірах. В них порушена їх власна структура» (Шестаков, 2015, с.85).

Іншими словами, коли порушується структура гештальту, будь-то структура особистості, або структура ситуації, що відбувається за рахунок усунення певних частин форми, автоматично створюється нова структура гештальту, але зі збереженням частини «духу», як виражався Арнхейм, попереднього гештальту.

Продовжуючи питання про формоутворення, слід сказати, що дослідників цікавив як естетично-пізнавально-художній аспект цього процесу, так i психологічно-психіатричний аспект. Обидві сторони складають ту філософську тканину форми, яка називається гештальт. Тому автор Ханс Принцхорн висловився так: «Ми шукаємо смисл кожної форми, яка формується у самому акті іiі формування» (Лэнге, 2017, с.156).

Смисл кожної форми Х. Принцхорн, психіатр, який досліджував художню творчість людей з психіатричними діагнозами, бачив у тому, що цей смисл кожної форми проявляється у відмові від раціонального утилітарного мислення, на користь спонтанного мислення, зорієнтованого на внутрішню реальність. Внутрішня реальність 3 іiі ірраціональним компонентом, та включає до себе 
певні перетворення реальності, але ці перетворення повинні носити імпульс для подальшого їі.

Тут велике значення мають такі поняття, як відстороненість та «порожнеча», які розкриває Ж.-М. Робін. Будь-яка ситуація, в якій бере участь індивід - це також гештальт. Гудмен стверджував, що «структура ситуації- це внутрішнє співпадання їі форми та змісту» (Робін, 2016, с.159).

В зв’язку з цим, продовжуючи думку про формоутворення у сучасному трактуванні гештальту, слід зазначити, що у сучасному світі з його швидкими змінами ситуацій, будь-яку ситуацію можна назвати ефемерною i невизначеною. Тому, ситуація як утворення, як гештальт, сама формує обмеження, звички, креативність рішень, зміну фігури та фону, а також власну тривалість.

Д. Гібсон виводить поняття «аффорданс» - властивість об'єкта, або середовища, які дозволяють проводити з об’єктом або середовищем певні дії. В ракурсі гештальт-підходу ще К. Левін висловлював думку, що речі ніби-то, нав'язують нам своїм зовнішнім поглядом, що з ними робити. Таким самим чином, певні ситуації продиктовані тими атрибуціями - зразками поведінки що вже є в нашій свідомості.

Д. Гібсон пропонував екологічний підхід до сприйняття речей і спочатку термін «аффорданс» (у перекладі «можливість») отримав широке розповсюдження у психології дизайну. Автор проводив думку, що ми можемо використовувати у об'єкті або ситуації не тільки ті властивості, які внутрішньо йому притаманні, а ті, які можна сприймати, виходячи зі своїх потреб, світобачення та власної креативності. Тобто, різні суб'єкти можуть сприймати різні аспекти та можливості одного і того ж гештальту. Це явище ми можемо спостерігати у сучасному мистецтві. Випливає ще один аспект естетичної складової гештальту - залученість - тобто, якість поглинання суб'єкта у певну ситуацію, або взаємодію 3 певним об'єктом, яка дозволяє створювати нові способи існування та функціонування об'єкта, або ситуації.

Сучасне трактування гештальту в певній мірі перегукується 3 екзистенційно - аналітичною теорією особистості, тому що саме цей напрямок приділяє багато уваги антропологічному аспекту гештальт-теорії. Будь-яка завершена структура - гештальт - у найвиразнішому своєму вигляді виступає, коли з одного боку, має нестандартні способи свого застосування, а з іншого - у тієї ситуації, яка має своє найдоцільніше втілення. Як наводить приклад А.Ленге, досліджувач екзистенційна аналітичного напрямку, «літак не перестає бути літаком, коли він рухається по землі. А лише коли він підіймається у повітря, він доводить, що він є літаком» (Лэнге, 2017, с. 17). Тобто, якщо розглядати людину як гештальт, як окремій світ переживань, думок, можна бачити, що найвищого свого втілення в антропологічному сенсі людина досягає, коли долає рівень певної природно-психологічної заданості, і має для цього можливість 3 точки зору різних ракурсів, або способів функціонування та розкриття особливості. 
Антропологічний прояв

сучасної

гештальт-теорії

передбачає

аутентичність. Відома теза гештальт-теорії, яку впроваджували класики, полягає в тому, що «людина постійно знаходиться у розвитку, але має зобов'язок через «Тут та Тепер» (Лэнге, 2017, с.107). Якщо розвинути цю думку, для повного функціонування будь-якого гештальту як конкретної особистості, або іiі певного психологічного прояву, особистість має потребу поглинання у свою аутентичність - персональну неповторну поведінку, прояв, вихід з ситуації, ідентичність собі: «Лише у співвідношенні 3 власною інтимністю ми $є$ не відлунням зовнішнього оригіналу, а співбесідником 3 власними переживаннями, ідеями, рішеннями» (Лэнге, 2017, с. 109). Аутентичність адаптує людину до світу. Іншими словами, саморегулювання активністю, тобто, формою пристосування об'єкту до середовища, надає особистості, можливість реалізовувати свою сутність.

Важливим моментом у розкритті власної аутентичності $є$ доступ до своїх почуттів, думок та емоцій. А. Ленге має думку, що «екзистенційний аналіз орієнтує людину на таку мету, як персонально обгрунтована екзистенція. 3 тієї точки зору все стає задачею: я для себе самого, світ, або має психічне порушення. Все кидає мені виклик та потребує, щоб якось з цим обійтись» (Лэнге, 2017, с. 121). Кожний гештальт, як структура, як утворення, повинен мати таку рису, як аутентичність для того, щоб він у подальшому розвитку змінювався, збагачувався, виходячи зі своїх власних закономірностей існування зі своїх власних закономірностей існування. Класична теорія гештальту (Д. Перлз, П. Гудмен, С. Гінгер) робить наголос на тому, щоб людина була відкрита діалогічному обміну з зовнішнім світом.

Сучасна гештальт-теорія також приділяє свою увагу обміну людини зі своїм внутрішнім світом. У такому обміні людина і розкриває свої почуття, думки та емоції. Гештальт-теорія робить особливий акцент на факті усвідомлення людиною будь-яких процесів та ситуацій. Сучасна гештальттеорія підкреслює, що доступ до своїх правильних почуттів та думок виникає, коли є відповідальність між змістом отриманого досвіду та сутністю людини: «Якщо людина щось може, якщо їй це подобається, якщо вона також баче, що має на це право, значить мова йде про істинно персональне, екзистенційне волевиявлення» (Робін, 2016, с. 127).

Коли є доступ до власної емоційної сфери, а також до своїх пізнавальних процесів, людина з більшою легкістю формулює свої фундаментальні цінності, які знаходять втілення у кожному досвіді, або ситуація тому, що кожний окремий досвід або окрема ситуація $є$ автономним гештальтом. Фундаментальні цінності і виступають фігурою у цьому гештальті. (Энрайт, 2002, с. 123).

Продовжуючи думку про те, як фундаментальні цінності формують досвід, а досвід, у свою чергу, впливає на фундаментальні цінності, слід сказати про нову течію у гештальт-теорії, яка стосується соціальної сутності гештальттеорії. (М. Спаниоло Лобб М, 2015, с. 56).

Низка сучасних авторів розкриває поняття «реляційний гештальт» тобто, динамічний гештальт», на який впливає відносність обставин. Серед цих 
авторів можна назвати М. Парлетт, Г. Йонтефа, Л. Джекобса, Г. Уілера. Кожна реальність враховує ту частину досвіду, яка бере участь у певній ситуації. При цьому особливе значення має відхід від інтрапсихологічної парадигми, в якій досвід береться всередині, і шлях до реляційної інтенціональності - прийняття існувань себе у взаємодії з тим світом, який на мене реагує.

М. Спаньоло Лобб, італійський автор, засновник італійського інституту гештальту має думку, що «антропологічна суть гештальт-підходу така: спонтанність людської натури зближує людину та природу, людину та соціальне середовище» (М. Спаниоло Лобб М, 2015, с. 42). Сучасна гештальттеорія розвиває думку про загальноприйняте поняття self, яке означає взаємодію між організмом та середовищем, доповнюючи це визначення ідеєю, що self - це функція, а не зміст. Це ще раз доводить ідею про реляційність гештальту.

Г. Йонтеф, доктор філософії у США, спирається на феноменологію: «Будьяке прийняття відносне: об'єкт сприймається з конкретної точки зору. Не існує суб'єктивного досвіду поза зв'язку 3 будь-яким зовнішнім об'єктом» (Филиппсон, 2016, с. 73). I якщо часто термін «реальність» сприймається, як щось окреме й автономно існуюче, теорія реляційного гештальту робить висновок, що те, що ми називаємо реальністю, будується виходячи $з$ елементів зовнішнього світу за трафаретами самого споглядача, тобто, певний гештальт, що існує у свідомості, бере безпосередню участь у спотворенні реальності. Сприйняття суб'єктом явища, ситуації, або сприйняття однією людиною іншою, є реальністю (Е. Медреш, 2009, с. 89).

Також у феноменології існує термін «брекетинг-ізолювання» у розрізі соціально-психологічних відносин - розгляд будь-якого явища без впливу певного особистісного досвіду». Цей термін уперше використаний Е. Гуссерлем. Г.Йонтеф підкреслює, що «у феноменології гештальту брекетинг допомагає досягнути взаєморозуміння» (Филиппсон, 2016, с. 75).

Підсумовуючи сказане вище, можна зробити висновок, що в результаті розгляду сучасної специфіки гештальту, можна виділити багато антропологічних аспектів, які висвітлюють широкий розбіг поглядів на проблему людини. Людина 3 позиції сучасної філософської антропології розглядається, як історія, яка сама створює власну замість та життєву програму дій.

Людина наповнює загальні категорії власним духовним смислом, тобто, гештальт у антропологічному аспекті розуміється як категорія, за допомогою якої людина транслює своє власне внутрішнє духовне наповнення у загальноприйнятих формах, які, наповнюючись, зазнають певних змін та перетворень.

Таке наповнення смислом і керує самим процесом формоутворення зі смислоутворенням має такі механізми:

- створення дистанції між об'єктом та середовищем;

- естетичні фактори, які передбачають $з$ одного боку стально існуючі канони, а з іншого - мінливість встановлених форм; 
- створення нових способів функціонування ситуації, або об'єкту;

- аутентичність, яка адаптує людину до світу за допомогою вірного доступу до власних емоцій, що сприяє більш легкому формуванню.

Реляційний гештальт впроваджує думку, що ніяка самосвідомість не може бути абсолютно вірною для теорії. Має сенс висновок про те, що гештальт є певною системою, яка розвивається за своїми законами, i, так само, як і будь-яка система, не $\epsilon$ самодостатньою. Для свого розвитку та збагачення гештальт повинен не тільки проводити асиміляцію зовнішньої інформації, але й здійснювати своєрідний діалог свого досвіду і нової інформації.

Діалог є ще одним антропологічним аспектом сучасного гештальту. Відомо, що одним з головних принципів діалогу є включеність. Включеність передбачає не тільки поглинання до внутрішніх аспектів життя або ситуації іншого, а ще й визнання іншого особою включеності. Г. Йонтер каже про те, що «включеність не може бути без емоційної присутності». (П. Филиппсон, 2016, c. 82). Тобто, діалог формується завдяки включеності обох сторін 3 участю емоцій, а конструктивний висновок діалогу формується завдяки створенню загального континууму усвідомлення реальності сторін, що створює гештальт як нову форму спілкування.

Людина має природну психофізіологічну здібність до вироблення свого власного засобу сприйняття світу за допомогою властивості мислити, за допомогою форм, образів, структур: «Відношення людини до світу і самої себе не визначається його інстинктивною програмою, а виробляється їм» (Горлач, Заветный, Кострикин, 2010, с. 141).

Висновки. Гештальт $є$ функціональною структурою, яка за притаманними їй законами впорядковує розмаїття окремих явищ, i цим це підтверджує ідею, що людина спроможна реагувати та змінювати свою самоідентичність, тобто, завдяки гештальту як своєрідному інструменту мислення людина може засвоювати та духовно перетворювати світ. Сучасна гештальт-теорія ставить нові стратегічні завдання в галузі міжособистісних відносин соціальних аспектів розвитку особистості та суспільства, а також пропонує варіанти їх рішення.

\section{СПИСОК ВИКОРИСТАНИХ ДЖЕРЕЛ}

Гингер С. Гештальт: искусство контакта./ Гингер С. - М.: Академический проект, 2010. $191 \mathrm{c}$.

Горлач Н., Заветный С.,Кострикин А., «Философия ценностей»/ Горлач Н., Заветный С., Кострикин А - Харьков «Сим», 2010 - 484c.

Лэнге А. Экзистенциально-аналитическая теория личности / Лэнге А. - М.: Генезис, 2017. $159 \mathrm{c}$.

Масколье Г. Выбери свою жизнь. Гештальт сегодня / Масколье Г. - М.: Академеческий проект, 2017. - $189 \mathrm{c.}$

Медреш Е. Идеи и отношения./ Медреш Е. - Харьков.: Око, 2009. - 144c.

Погодин И.А. Диалогово-феноменологическая психотерапия: ресурсы первичного опыта: в 5 томах. - Т2 (10): Фундаментальный парадокс присутствия и теория поля в психологии переживания / Погодин. - К, 2013. - 108 с. 
Теория поля в гештальт-терапии: контакт и отношения. - Казань: Изд-во Казанского университета, 2016. - 127 с.

Робін Ж.-М. Социальные изменения начинаются вдвоем. Эссе по гештальт-терапии./ Робін Ж.-М. - М.:ИОИ, 2016-276с.

Спаниоло Лобб М. Сейчас-ради-потом в психотерапии: гештальт-терапия, рассказанная в обществе эпохи постмодернизма / Спаниоло Лобб М. - Ростов н/Д: Феникс, 2015. $366 \mathrm{c}$.

Хломов Д. Философия гештальт-подхода. / Хломов Д., Калитеевская Е.- М, 2008. - 77 с.

Энрайт Д. Гештальт, ведущий к просветлению. / Энрайт Д. - М. ЭКСМО. - 2002 г. - 91 с.

Шестаков В.П. «Гештальт и Искусство. Психология искусства Рудольфа Арнхейма»/ Шестаков В.П - СПб: Алетейя, 2015 -112 с.

ТАТЬЯНА КОЛЫЧЕВА кандидат философских наук, дочент кафедры философии и сочиологии,

Украинский государственный университет железнодорожного транспорта (2. Харьков, Украина) e-mail: kolychevatatjana@ukr.net,.ORCID 0000-0001-7710-5319

ВАДИМ ЛЕБЕДЕВ кандидат философских наук, дочент кафедры философии и сочиологии,

Украинский государственный университет железнодорожного транспорта (2. Харьков, Украина) e-mail:wz551a@gmail.com ORCID 0000-0002-8673-7075

\section{СОВРЕМЕННАЯ ТРАКТОВКА ГЕШТАЛЬТА: АНТРОПОЛОГИЧЕСКИЕ АСПЕКТЫ}

Важную роль в современной трактовке гештальта является его рассмотрение не только с эпистемологических позиций, но и с точки зрения саморефлексии человека. Таким образом, современный антропологический измерение гештальта заключается в том, что познание личности нужно осуществлять, исходя из процесса ее индивидуализации. То есть, важен сам процесс процесс формообразования. Рассмотрим способы достижения этого. Идеи современного гештальта перекликаются с мыслями экзистенциально-аналитической территории личности. Процесс приобретения любым объектом или явлением своей формы, особенно когда речь идет о человеческой личности и границы ее проявлений, начинается с создания дистанции между объектом и тем, что его окружает. Именно дистанция позволяет индивиду выяснить свои имплицитные чувства. То есть, картина мира личности строится на том резонансе, который человек получает в ответ на свои чувства и эмоции, но при этом резонанс может происходить либо в форме конструкции, или в форме реконструкции. Большое значение придается эстетический аспект создания гештальта. В рамках созданного гештальта человек приспосабливается к реальности и одновременно приспосабливает к себе реальности тем, что она ищет способы не только понять для себя реальность, но и сделать ее эстетически благоприятной. Таким образом, в рамках современной гештальт-теории эстетический фактор создания формы заключается в сочетании достижимого на познавательном и эмоциональном уровнях без ссылки на определенные ценности. Другими словами, когда нарушается структура гештальта, будь то структура личности, или структура ситуации происходит за счет устранения определенных частей формы, автоматически создается новая структура гештальта, но с сохранением части предыдущего гештальта. Антропологический проявление современной гештальт-теории предполагает аутентичность. Внутренняя реальность с ее иррациональным компонентом, и включает в себя определенные преобразования реальности, но эти преобразования должны носить 
импульс для дальнейшего ее развития. Современная гештальт-теория подчеркивает, что доступ к своим правильных чувств и мыслей возникает, когда есть ответственность между содержанием полученного опыта и сущностью человека. Ряд современных авторов раскрывает понятие «реляционный гештальт» есть, динамичный гештальт», на который влияет относительность обстоятельств. Диалог является еще одним антропологическим аспектом современного гештальта. Известно, что одним из главных принципов диалога включенность. Включенность предполагает не только поглощение к внутренним аспектам жизни или ситуации другого, но и признание другого лицом включенности. То есть, диалог формируется благодаря включенности обеих сторон с участием эмоций, а конструктивный вывод диалога формируется благодаря созданию общего континуума осознания реальности сторон, создает гештальт как новую форму общения. Современная гештальт-теория ставит новые стратегические задачи в области межличностных отношений социальных аспектов развития личности и общества, а также предлагает варианты их решения.

Ключевые слова: гештальт; антропология; реляционный гештальт; аутентичность; эстетический аспект; диалог; континуум осознания.

TETYANA KOLYCHEVA Ph.D., Associate Professor of the Department of Philosophy and Sociology Ukrainian State University railway transport (Kharkov, Ukraine) e-mail: kolychevatatjana@ukr.net, ORCID 0000-0001-7710-5319

VADYM LEBEDEV

Ph.D., Associate Professor of the Department of Philosophy and Sociology Ukrainian State University railway transport (Kharkov, Ukraine) e-mail:wz551a@gmail.com ORCID 0000-0002-8673-7075

\section{MODERN INTERPRETATION OF GESTHALT: ANTHROPOLOGICAL ASPECTS}

Introduction. The important role of the modern interpretation of Gestalt is not only seen from the epistemological positions, or from the point of view of the self-reflection of the people. Thus, the current anthropological vision of the Gestalt of the Poleag is in fact, in particular, the special features of the healty, the progress of the it. The importance of the process itself is the formatting process. Analysis of publications. The current status of the article is related to the need to develop the tools of this self-identified people for self-importance in other anthropological aspects. Characteristics of perception as the processes of the emergence of persistent images were studied in classical philosophy, in particular, by such philosophers as Aristotle, D. Locke, I. Kant and representatives of the Wurtzburg School of Gestalt-direction, as the theory of a holistic perceptual image and developed by the representatives of $\mathrm{H}$. Eerenfels. The main methodological principle of the theory of gestalt is E. Husserl, M. Merlot-Ponty, M. Anri, J. L. Marion. The purpose of the article is to study the concept of "Gestalt" in the philosophical and anthropological aspect for the structuring, generalization and functioning of cultural experience. Results. Particularly important are the people who can live in the light of the modern informational space. By way of statistics is studying the concept of "gestalt" in the philosophical and anthropological aspect for the structure of a government, which is a function of a cultural experince. Objectively, the concept is "gestalt", which means the structure, image, form, confession, language, followed by the laws of the order of the names of anthropological organizations. Let's take a look at how to achieve this. The ideas of modern Gestalt to get a little banged up with dummies of existential-analogical territory. The process of confrontation is whether it is a manifestation of its own form, especially if there is a special focus on the boundaries of the manifestations, follow the distance from each other. Within the framework of the created gestalt, a person adapts to reality and at the same time adapts reality to himself by the fact that she is looking for ways not only to understand reality for herself, but also to 
make it aesthetically favorable. Thats, the picture of the peculiarity will be on that resonance, which is the people's answer, which will be appreciated at the same time, but at the same time, the resonance can be made in the form of the design, or in the form of the reenactment. Great value is given to the aesthetic aspect of the gestalt movement.. Thus, within the framework of such Gestalt theory, there is a natural factor in shaping the formation of the Polagan in a long-term extension of the capital and economic direction without favoring singing. In other words, if the structure of a gestalt is torn down, whether it is a special structure, or a situation structure, you'll go beyond the drawing of the singing parts, the new structure of the Gestalt will automatically open, or a third side of the saved part of the front gest, and the whole gest, and the whole of the top gesture will form, and the other side will be replaced by the best gest, and the whole of the top gesture will be replaced by the best gest, and the whole will of the opposite side of the top gest, The anthropological manifestation of the all-inclusive gestalt - theory of transmission is authentic. The internal reality of the is the irracial component, which includes to itself the singing transformation of reality, and the transformation of personal responsibility for the subconscious distribution. Such postmodernist theories of the subjectivity may be meaningful for the complete gestalt in the anthropological aspect. Dialogue is one more anthropological aspect of the important gestalt. It is known, that one of the main principles for dialogue is included. The inclusion of the gear is not just a glance to the internal aspects of life or a situation of life, but also a special life. Thats, dialogue can take place between the two sides of the party, and constructive projects can form the door of the constellation of the reality of the parties, created by the gestalt yak new shape. Conclusion. Modern Gestalt theory sets new strategic tasks in the field of interpersonal relations of the social aspects of the development of a person and society, and also offers options for solving them.

Keywords: gestalt; anthropology; relational gestalt; authenticity; aesthetic aspect; dialogue; continuum of awareness.

\section{REFERENCES}

Gy`nger, S. (2010). Geshtal`t: y`skusstvo kontakta. Gy`nger S. Akademy`chesky`j proekt. 191s. Gorlach N., Zavetnij S., Kostry`ky`n A., (2010) «Fy`losofy`ya cennostej». 484s.

Lenge A. (2017). Ekzistentsialno-analiticheskaya teoriya lichnosti. 159 s.

Maskole G. (2017). Vyiberi svoyu zhizn. Geshtalt segodnya. 189 s.

Medresh E. (2009). Idei i otnosheniya. Harkov.: Oko. 144s.

Pogodin I.A. (2013). Dialogovo-fenomenologicheskaya psihoterapiya: resursyi pervichnogo opyita:v 5 tomah. - T2 (10): Fundamentalnyiy paradoks prisutstviya i teoriya polya $\mathrm{v}$ psihologii perezhivaniya. Pogodin. $108 \mathrm{~s}$.

Fylyppson P. (2016). Teoriya polya v geshtalt-terapii: kontakt i otnosheniya. - Kazan: Izd-vo Kazanskogo universiteta. $-127 \mathrm{~s}$.

Robin Zh. (2016). Sotsialnyie izmeneniya nachinayutsya vdvoem. Esse po geshtalt-terapii.- 276s.

Spaniolo Lobb M. (2015). Seychas-radi-potom v psihoterapii: geshtalt-terapiya, rasskazannaya $\mathrm{v}$ obschestve epohi postmodernizma. Rostov: Feniks. $366 \mathrm{~s}$.

Hlomov D. (2008). Filosofiya geshtalt-podhoda. 77 s.

Enrayt D. (2002). Geshtalt, veduschiy k prosvetleniyu. $91 \mathrm{~s}$.

Shestakov V.P. (2015) «Geshtalt i Iskusstvo. Psihologiya iskusstva Rudolfa Arnheyma». $112 \mathrm{~s}$.

\section{Надійшла до редакції 10.05.2019}

